\title{
Impovement of some functional properties of cookies with added natural components of pumpkin and chia
}

\section{Iryna Ditrich, Valeriia Moiseieva}

\author{
National University of Food Technologies, Kyiv, Ukraine
}

Keywords:

Cookie

Shortbread

Pumpkin

Chia

Seeds

Functional

Article history:

Received 30.05.2017

Received in revised

form 14.07.2017

Accepted 05.09.2017

\section{Corresponding} author:

Iryna Ditrich

E-mail:

irindtr@gmail.com

DOI: $10.24263 / 2310-$

1008-2017-5-1-13

\section{Abstract}

Introduction. Conducted analytical and experimental studies to increase biological value the recipe of the shortbread cookie "Pumpkin", the choice of using pumpkin puree, pumpkin oil and chia seeds has been substantiated for creation a functional food product.

Materials and methods. The optimum balance of hydrolyzed pumpkin puree to sand sugar, pumpkin oil to butter and the required amount of chia seeds was determined was determined by mathematical modeling. Mass fraction of sugars was determined due to AOAC Method 10-52, moisture - AOAC 934.01, fat - AOAC 963.15. Ash test was carried out based on AOAC 923.03. Water absorption AOAC 960.14.

Results and discussion. The results showed that the sample of cookie with addition of pumpkin puree $50 \%$ and pumpkin oil $20 \%$ of the initial laying of raw materials and chia seeds in the proportion of $1.5 \%$ of the wheat flour amount had the best indicators. Pumpkin puree addition to the sandy paste has affected the structure and consistency of the products. The introduction of puree to the cookie has caused more intensive taste and aroma, a golden color, and it has stabilized the shape and surface.

The usage of pumpkin puree has led to a change of the products' color from light yellow to light orange, due to the presence of beta-carotene. Reducing of the norm of sand sugar has led to a decrease of the energy value of finished goods from 467 to $402.5 \mathrm{kcal}$. The structure of the cookie has become more fragile and tender, which was noted by the tasters as a positive effect.

Organoleptic and physicochemical indicators (mass fraction of moisture $-13,2 \%$; ash $-0,1 \%$; mass fraction of sugars $30 \%$; mass fraction of fat $-3,4 \%$; water absorption $157 \%$ ) confirm that the selected additives do not change the basic characteristics of the cookie.

Conclusion. Using a mixture of pumpkin puree, pumpkin oil and chia seeds in the production led to a reduction in the energy value of finished products by reducing the amount of sugar. 


\section{Introduction}

Nowadays, the sharp increase in the number of chronic diseases in the countries of eastern Europe population is noticed. It is deeply connected with a violation of the food quality. Thus, everyday nutrition includes fats of animal origin and simple carbohydrates in a significant amount, while there is a scarcity of protein consumption, macro- and micro elements, dietary fibers, vitamins and other biologically active substances [1].

The analysis of the assortment structure, volumes of production and the level of consumption of confectionery products by the population of Eastern Europe allows to consider confectionery products made of flour as functional products, which can satisfy various consumer needs. Most of them are characterized by such criteria: attractive appearance, energy value that is high enough, and also, they include proteins, not only carbohydrates and fats [2].

Cookies are probably one of the most commonly used products made of flour by the confectionery industry. This is a favorite delicacy of millions of adults, as well as of children whose body needs nutrients inflow for normal development. Thus, the development of shortbread cookie recipe of increased biological value is one of the priority tasks for modern confectionery industry.

Excessive consumption of animal fats, that are usually present in large numbers in cookie recipes, leads to deterioration of human health and intensification of many diseases. Therefore, it is possible to increase the competitiveness of this group of products in modern conditions is possible by pumpkin oil usage, which contains a significant amount of essential polyunsaturated fatty acids $\omega-3$ and $\omega-6$. In addition to this, they are the source of essential substances for human bodies (phospholipids, fat-soluble vitamins, sterols, etc.), and this fact makes them indispensable components of nutrition [3].

For the development of the new type of cookie recipe of increased biological value as a source of useful substances, such ingredients were chosen: pumpkin puree, pumpkin oil and chia seeds. All these natural and physiological functional products contain a significant amount of dietary fibers, polyunsaturated fatty acids, vitamins (B, A, D, K, E, C, $\mathrm{PP}$ ), macro- and microelements (potassium, calcium, magnesium, sodium, phosphorus), iron, boron, iodine, manganese, copper, selenium, zinc, etc.), which are essential for healthy life [1].

The purpose of the research is to determine the properties of the shortbread cookie "Pumpkin" with the adding of pumpkin puree, pumpkin seeds and chia seeds, and to determine it nutritional properties.

\section{Analysis of recent research and publications}

During the research of scientific works of Denisenko T.M., Kozlova A.V., Iorgacheva K.T., Sirokhman I.V. [2-5], devoted to the development of the shortbread cookie recipe with various additives, it was determined that the usage of pumpkin puree dietary fibers and its oil as functional components is the most expedient. They significantly improve the organoleptic properties of products and give an attractive yellow-orange color and harmonious fragrance.

Pumpkin is a kind of natural vitamin and mineral complex. It is widely grown, is unpretentious and well stored throughout the year Table 1 shows the nutritional content of pumpkin [4]. 
Table 1

Nutritional content of pumpkin [8]

\begin{tabular}{|l|c|}
\hline \multicolumn{1}{|c|}{ Nutrients } & Content in 100g \\
\hline Protein, g & 1.0 \\
\hline Fat, g & 0.1 \\
\hline Carbohydrates, g & 4.4 \\
\hline Food fibers, g & 2.0 \\
\hline Ash, Mr. & 0.6 \\
\hline Starch, g & 0.2 \\
\hline Organic acids, g & 0.1 \\
\hline Mono and disaccharides, g & 4.2 \\
\hline Mineral substances, mg: & \\
\hline Calcium & 204.0 \\
\hline Magnesium & 14.0 \\
\hline Sodium & 4.0 \\
\hline Potassium & 204.0 \\
\hline Phosphorus & 25.0 \\
\hline Iron & 0.4 \\
\hline Zinc & 240 \\
\hline Copper & 180 \\
\hline Vitamins, mg & 0.05 \\
\hline Vitamin B1 & 0.06 \\
\hline Vitamin B2 & 0.1 \\
\hline Vitamin B6 & 14.0 \\
\hline Vitamin B9, $\mu$ g & 8.0 \\
\hline Vitamin s & 1.5 \\
\hline Vitamin a & 0.5 \\
\hline Vitamin PP & 89.02 \\
\hline Energy value, kJ & \\
\hline \multicolumn{2}{|c|}{} \\
\hline \multicolumn{2}{|l|}{} \\
\hline
\end{tabular}

That is why the development of food products with pumpkin content is appropriate. It allows to create fundamentally new products with the perfect content of nutrients and excellent organoleptic properties. In addition, they have prophylactic and bio corrective effect [5].

Pumpkin was introduced into a new recipe in the form of pumpkin puree [6]. The chemical composition of used hydrolyzed pumpkin puree with a $10 \%$ of mass fraction of solid matter (MFHR) is given in Table 2.

Chemical composition of hydrolyzed pumpkin puree [6]

Table 2

\begin{tabular}{|l|c|}
\hline \multicolumn{1}{|c|}{ Indicator's name } & HHP \\
\hline MFHR, \% & $10 \pm 0.5$ \\
\hline Active acidity, $\mathrm{pH}$ & $3.2 \pm 0.1$ \\
\hline Total sugar content, \% & $7.5 \pm 0.5$ \\
\hline Content of water-soluble pectin, g/100 g & $2.7 \pm 0.1$ \\
\hline Degree of pectin esterification & $60 \pm 2.0$ \\
\hline Cellulose content, g / 100 & $2.1 \pm 0.1$ \\
\hline
\end{tabular}


Due to the high content of dietary fiber, pectin and other nutrients, hydrolyzed vegetable raw material is selected for usage in order to improve the new type of confectionery product made of flour.

Pumpkin oil effects on the nervous system are widely known. It helps to get rid of sleep disturbances, migraine and headaches, chronic fatigue, stress, its light sedative effect restores calmness and calmness [5].

Chia, or Salvia Spanish (Lat. Salvia hispanica) is a species of flowering plant in the mint family, Lamiaceae. Its close related spicies Salvia columbariae is also often used. The native land of the plant is Central and South Mexico as well as Guatemala. Today chia is cultivated in many countries in South America and Australia [7]. According to the analysis of literary sources, chia seeds contain twice as much protein as eggs and seven times more than in milk. Also, in Chia there are 3 times more fat than in eggs, 4 times more than in fish, 5 times more than in meat and 15 times more than in milk. Content of $\omega-3$ unsaturated fatty acids in chia seeds is 4 times greater than in the above-mentioned products (see Table 1). The content of mineral substances and vitamins in the seeds of chia is very high in comparison with products of animal origin, comparing the content of such elements as calcium, magnesium, phosphorus, iron, copper and vitamins B9 and C [8-9].

\section{Materials and methods}

According to the aim, the stages of the research were identified in such way: analysis of the chemical composition of new raw ingredients; identification of the optimal composition of the recipe, which could provide high sensory properties of the product; development of the shortbread cookie "Pumpkin" recipe of functional purpose; study of sensory, physical and chemical indicators of the obtained biscuits.

The optimum ratio of three kinds of meal composition was determined by mathematical modeling [9].

\section{Production of research sample}

Shortbread dough with the addition of the estimated number of meal and reference sample for recipe shortbread cookies was prepared according to the method of AACC [13] with some modifications in the recipe, technological card shown in Table $3[10,11]$.

The recipes of samles of shortbread cookies "Pampkin" are shown in Table 3.

The cookies were cooked with usage of all the food ingredients: the butter was churned for 5-6 minutes. Other ingredients were added in such sequence: whole egg, sugar and vanilla powder, pumpkin puree and oil. They were churned well again, then flour and chia seeds were added into pastry and it was being churned for $1 \mathrm{~min}$. The ready dough was transported into a piping bag and laid through a toothed nozzle of "tubules" with a diameter of 10-12 mm on a dish and baked for 14 minutes with temperature of $200{ }^{\circ} \mathrm{C}$.

Sensory properties of cookies were determined using a twenty-member panelist. Participants were asked to evaluate the coded samples for smell, taste, color and form texture. Each sensory attribute was evaluated on a 5-point scale $(1=$ extremely disliked, and $5=$ very much) and seems like polygon for best described results was made Figure 1 . Shortbread profile was defined by calculation method [12]. 
Recearched recipes of shortbread cookies "Pampkin" of a functional purpose

\begin{tabular}{|c|l|c|c|c|c|}
\hline \multirow{2}{*}{$\begin{array}{l}\text { No. } \\
\mathrm{z} / \mathrm{p}\end{array}$} & Name of raw materials & \multicolumn{4}{|c|}{ Calculation per 1 kg of finished goods (g) } \\
\cline { 3 - 6 } & & Cookie & $\begin{array}{c}\text { Sample № } \\
1\end{array}$ & $\begin{array}{c}\text { Sample № } \\
2\end{array}$ & $\begin{array}{c}\text { Sample № } \\
3\end{array}$ \\
\hline 1 & $\begin{array}{l}\text { Fancy white wheat } \\
\text { llour }\end{array}$ & 614 & 600 & 600 & 600 \\
\hline 2 & Butter & 400 & 360 & 320 & 340 \\
\hline 3 & Powdered sugar & 123 & 73.8 & 61.5 & 61.5 \\
\hline 4 & Whole egg & 31 & 31 & 31 & 31 \\
\hline 5 & Vanilla powder & 3.1 & 3.1 & 3.1 & 3.1 \\
\hline 6 & Pumpkin puree & - & 49.2 & 61.5 & 61.5 \\
\hline 7 & Pumpkin oil & - & 40 & 80 & 60 \\
\hline 8 & Chia seeds & - & 15 & 15 & 15 \\
\hline
\end{tabular}

\section{Physical and chemical analysis}

Mass fraction of sugars was made as directed in the AACC Method 10-52 [13].

Mass fraction of moisture was determined based on AOAC Method 934.01: Air Oven Method [14].

Mass fraction of fat was conducted based on AOAC Method 963.15: Soxhlet Extraction Method utilizing petroleum ether as solvent [14].

Ash test was carried out based on AOAC Method 923.03: Dry Ashing Method [14].

Water absorption was determined using standard AOAC Method 960.14: Adsorption Indicator Method [14].

The Calorie content level in a cookie "Pumpkin" placed be calculated by the method of determining the amount of energy released from chemical compounds that are part of the product in the process of biological oxidation of them in an organism used to provide physiological functions of the organism [15]. Method uses the average values of $4 \mathrm{Kcal} / \mathrm{g}$ for protein, 4 $\mathrm{Kcal} / \mathrm{g}$ for carbohydrate, and $9 \mathrm{Kcal} / \mathrm{g}$ for fat.

\section{Results and discussion}

According to the results of the organoleptic evaluation of the shortbread cookies, a «profilogram» (Fig. 1) was constructed. It proofs that the best organoleptic quality indices are obtained in sample № 2 of cookie with addition of pumpkin puree $50 \%$ and pumpkin oil $20 \%$ of the initial laying of raw materials and chia seeds in the proportion of $1.5 \%$ of the wheat flour amount had the best indicators.

The addition of pumpkin puree to the shortbread dough has affected the structure and consistency of the products. The introduction of puree has caused an increase of cookie's taste and aroma, a golden color, a stabilization of the shape and surface.

The use of pumpkin puree has led to a change in the color of products: from light yellow to light orange, due to the presence of beta-carotene. 
Reducing the norm of powdered sugar led to a decrease of the caloric value of finished goods.

The structure of the cookie has become more fragile and tender, which was noted by the tasters as a positive effect. Thus, a positive influence on the organoleptic parameters of finished goods is shown.

Regarding physical and chemical indicators, the results of the research revealed that all of them are situated within the norms presented for cookie requirements, shown in Table 4. 5.

The caloric value of the cheque and enriched shortcut biscuit sample is shown in Table

Based on the results of studying the caloric value indices, it is concluded that the cookie "Pumpkin" has a lower calorie content in comparison with a cheque sample of 78.0 $\mathrm{kcal} / 324.48 \mathrm{~kJ}$.

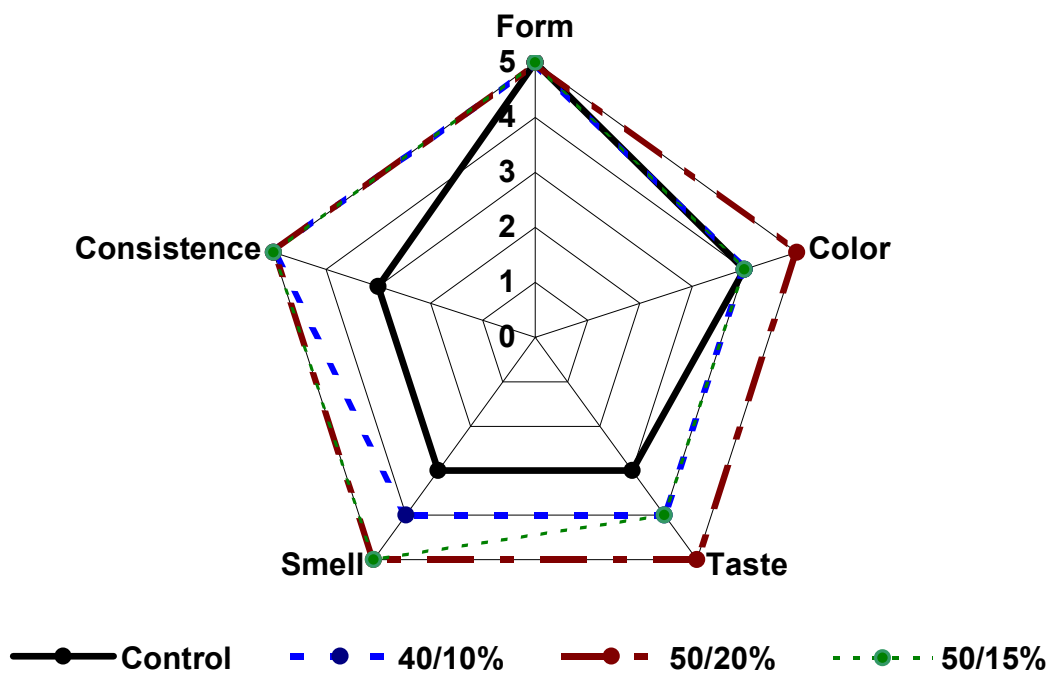

Figure 1. Aroma cookie cooker "Pumpkin"

Table 4

Results of studying the physical and chemical quality indicators of shortbread cookie of increased biological value

\begin{tabular}{|c|c|c|}
\hline Indicator's name & $\begin{array}{c}\text { Cookie } \\
\text { requirements }\end{array}$ & $\begin{array}{c}\text { Cookie } \\
\text { "Pumpkin" }\end{array}$ \\
\hline Mass fraction of moisture, \% & Not more than 15.5 & $13.2 \pm 0.4$ \\
\hline $\begin{array}{c}\text { Mass fraction of sugars (in } \\
\text { terms of dry solids), \% }\end{array}$ & Not less than 12,0 & $30 \pm 1.1$ \\
\hline Ash, \% & Not more than 0,1 & $0,1 \pm 0.1$ \\
\hline $\begin{array}{c}\text { Mass fraction of fat (in terms } \\
\text { of dry solids), \% }\end{array}$ & Not less than 2,3 & $3.4 \pm 0.1$ \\
\hline Water absorption, $\%$ & Not less than 110,0 & $157 \pm 2.0$ \\
\hline
\end{tabular}


The obtained results of Table 3, confirmed that the selected additives do not affect the results of researches and do not change the basic characteristics of the cookie, because all are within the norm for conventional cookies.

Caloric value of the cheque sample

Table 5

\begin{tabular}{|l|c|c|}
\hline \multicolumn{1}{|c|}{ Nutritional value } & Cheque sample, 100 g & "Pumpkin" cookie's sample, 100g \\
\hline Proteins, $\mathrm{g}$ & 6.1 & 6.4 \\
\hline Fat, $\mathrm{g}$ & 18.8 & 20 \\
\hline Carbohydrates, $\mathrm{g}$ & 68.9 & 55 \\
\hline Caloric value, $\mathrm{kcal} / \mathrm{kJ}$ & $467 / 1942,7$ & $402.5 / 1674$ \\
\hline
\end{tabular}

Using a mixture of pumpkin puree, pumpkin oil chia seeds in the production of "Pumpkin" cookies led to a reduction in the energy value of finished products from 467 to $402.5 \mathrm{kcal}$ by reducing the amount of sugar.

\section{Conclusions}

A new type of cookie "Pumpkin" has the high biological value due to the introduction of raw materials of plant origin into its composition - hydrolysed pumpkin puree and pumpkin oil, chia seeds. Samples of a new product are made. The optimal concentration of pumpkin puree, pumpkin oil and chia seeds for harmonic taste and smell are established. Sensory, physical and chemical parameters are investigated.

According to the results of the study, the patent of Ukraine for the useful model of shortbread cookie "Pumpking" was received.

\section{References}

1. Shibata M., Koji O., Toyoaki M. (2017), The role of adipokines in cardiovascular disease, Journal of Cardiology, 4(12), pp. 329-334.

2. Sharafbafia N., Toshb S., Alexandera M., Corred M. (2014), Phase behaviour, rheological properties, and microstructure of oat $\beta$-glucan-milk mixtures, Food Hydrocolloids, 2(2), pp. 274-280.

3. Kozlova A., Nomofmolova N. (2003), Public nutrition, Publishing House "Economic News", Minsk.

4. Denisenko L. (2013), Development of technological systems of confectionery industry, Flour confectionery, 1(2), pp. 302-304.

5. Denisenko L. (2005), Flour confectionary products of increased biologic value, Bulletin of the KNEA, 3 (6), pp.181-186.

6. Kuprienko S.A. (2013), General History of the Things of New Spain., Aesthetic Knowledge in the Medicine and Botany, Publisher Kuprienko S.A., Kyiv.

7. Kon I. (2012), Medical and biological justification for the use of flour made of chia seeds in nutrition of children over three years old, Food Nutrichion 4(10), pp.120-123. 
8. Zapototska V. (2012), Vukorustannya harchovuh volokon pru vurobnutstvi rusovogo korpusu dlya koekstryziynuh prodyktiv, Ukrainian Food Journal, 3, pp. 27-30.

9. Djuruk P., Kovalchyk P. (2008), Novi vudu hlibobulochnih vurobiv pidvuschenoyi harchovoi tsinnosti, Hlebopekarskoe i konditerskoe delo, 1, pp. 18-19.

10. Vasilica N. (2011), Strong flour improvement using maltflour, Journal of Agroalimentary Processesand Technologies, 15(2), pp. 242-244.

11. Sidorova N., Glovenko V. (2008), Pischevie volokna v proizvodstve konditerskih isdeliy, Konditerskoe proszvodstvo, 2, pp.18-20.

12. Samohvalova V., Kasabova R. (2011), Zbagachennya mafiniv harchovumi voloknami, Naykovi pratsi ONAHT, 40(1), pp. 161-163.

13. AACC (2000), Approved Methods of American Association of Cereal Chemists, Cereal Laboratory Methods., St. Paul. Minn.

14. AOAC (2000), Official Methods of Analysis, Association of Official Analytical Chemists, Washington, DC, USA, 10th edition.

15. Manual P. (2001), Calorimeter Operating Instruction Manual. Parr Instrument Co.; Moline, ILL., USA. 